\title{
Pensononowoor
}

2014, vol. 71, 15-22

http://dx.doi.org/10.12657/denbio.071.002

Vitas Marozas

\section{Effect of the coniferous forest - grassland edge on ground vegetation in the mixed European forest zone, Lithuania}

\author{
Received: 27 July 2012; Accepted 14 May 2013
}

\begin{abstract}
The objective of this study was to estimate the edge effect on the species richness in agriculturally maintained forest-grassland boundaries of coniferous forest and to determine how species respond to a forest edge. We hypothesised that species number, cover of herbs and mosses is higher in the edge, and species penetrates from nearby grasslands into forest interior. The study was conducted in the Southwestern Lithuania. The edge effect on overall herbaceous species composition of coniferous forests was evaluated by Canonical Correspondence Analysis. The species richness of herbs and mosses in the coniferous forest was highest in the forest edge and declined towards interior. The highest decrease in the number of species occurred within 0 to $5 \mathrm{~m}$ to the edge. The highest cover of herbs and mosses was in the forest edge and decreased towards the forest interior. CCA biplot showed a good correlation of overall species composition and the distance to the forest edge. Distribution of species along edge to interior gradient depended on the species response to different ecological factors. Ellenberg value of light was higher in the edge. Ellenberg value of nitrogen was higher in the forest interior.
\end{abstract}

Additional key words: canonical correspondence analysis, Ellenberg indicator values, forest edge effect, forest fragmentation, species richness

Address: Institute of Environment and Ecology, Aleksandras Stulginskis University, Studentu 11, Lt-53361 Akademia, Kaunas r., Lithuania; Fax +370 7 752224; e-mail vitas.marozas@asu.lt

\section{Introduction}

Fragmentation changes the spatial structure of the landscape, increases the amount of edges and induces changes in the abiotic and biotic environment. Fragmentation and habitat loss are among the most important causes of species composition change (Murcia 1995; Haila 1999; Ries et al. 2004). In many parts of mixed European forest zone, forest harvesting system has transformed the forest landscape into patch- es of forest islands of various sizes. Forest islands are often isolated from one another by open fields. One consequence of fragmentation is decreasing proportion of interior habitat and increasing proportion of the edge (Murcia 1995; Haila 1999; Matlack and Litvaitis 1999).

Forest fragmentation necessary leads to an increase in the amount of forest edge. Changes in abiotic and biotic conditions in the edges compared with the interior habitat are called edge effect. These effects 
are numerous, including changes in wind, humidity, throughfall deposition, radiation, predation, parasitism, and species interactions (Murcia 1995; Donovan et al. 1997; Brazaitis et al. 2005; Wuyte et al. 2008; Marozas et al. 2009). Compared with interiors, forest edges typically have different plant species composition and community structure. Edges influence both the ecosystem structure and function through changing pathways of exchange of energy, materials, and organisms between patches (Chen et al. 1995). At the ecosystem level, processes such as primary production and decomposition can be altered near edges relative to interior patch conditions (Chen et al. 1992).

Changes in structure, composition and function of edges primarily result from the alteration of microclimate, following the structural modification of the landscape. Microclimate, including solar radiation, moisture, wind, and temperature, is a primary driver of ecosystem and landscape-level processes such as photosynthesis, regeneration, plant growth, nutrient cycling, and decomposition (Perry 1994). At forest edges microclimatic variables (light intensity and duration, relative humidity, air temperature) and soil factors $(\mathrm{pH}$, organic carbon, total nitrogen, available phosphorus, soil moisture and temperature) change fast over short distances. In comparison with forest interior conditions, edges are generally characterised by higher light, air and soil temperature, wind speed, lower relative humidity and soil moisture as well as by soil processing higher levels of organic carbon, $\mathrm{pH}$, total nitrogen and available phosphorus (Brothers and Springarn 1992; Brothers 1993; Matlack 1993; Young and Mitchell 1994; Camargo and Kapos 1995; Chen et al 1996; De Casenave et al. 1995; Jose et al. 1996; Didham and Lawton 1999).

In response to these conditions, vegetation structure and composition in the edge is different than that in the forest interior. Typical vegetation responses to the edge environment include increased presence of invasive or exotic species (Brothers and Springarn 1992; Fraver 1994; Cadenasso and Pickett 2001; Lin and Cao 2009), increased sapling and tree densities (Brothers and Springarn 1992; Chen et al. 1992; Brothers 1993; Fraver 1994), increased shrub cover (Matlack 1994), and higher species richness (Brothers and Springarn 1992; Fraver 1994). Tree species distribution may also vary with distance from the forest edge (Whitney and Runkle 1981; Brothers 1993; Hamberg et al. 2008), as may be tree mortality from wind throw (Chen et al. 1992; Young and Mitchell 1994; Jönsson et al. 2007).

To counteract the negative edge effect it is important to understand how species respond to conditions in habitat edges (Haila 1999; Fletcher 2005). Forest edges are preferred habitat of many species; some of them are edge specialist. Edges of forest fragments are easily invaded by species from surrounding ecosystems and some species may continue invade through the forest edge into interior. Edge habitat is unsuitable for species requiring interior habitat and consequently such species may be lost if fragments become too small (Haila 1999; Harper et al. 2005).

It is important to know the extent edge effects penetrate into the forest. Knowledge of edge width is critical for the management focusing on the preservation of natural forest characteristics (Brothers 1993) and for setting priorities for conservation. Edge effects are the most significant consequences of fragmentation resulting from natural and human-caused disturbances. The area influenced by edges is an important measurement for ecological studies and natural resource management. A few studies on plant species richness on man-made forest boundaries have been conducted in European forest zone (Luczaj and Sadowska 1997; Honnay et al. 2002; Marozas et al. 2005; Orczewska and Glista 2005; Hamberg et al. 2008, 2009).

The aim of this study was to estimate the edge effect on the species richness in agriculturally maintained forest-grassland boundaries of coniferous forest and to determine how species respond to the forest edge. We hypothesised that species number, cover of herbs and mosses is higher in the edge, and species penetrates from nearby grasslands in the forest interior.

\section{Methods}

\section{Study area}

The study area is located in South-western Lithuania $\left(54^{\circ} 21^{\prime}-54^{\circ} 55^{\prime} \mathrm{N}, 23^{\circ} 29^{\prime}-23^{\circ} 41^{\prime} \mathrm{E}\right)$. The study area falls in the transitional deciduous coniferous mixed forest zone of Europe (Ahti et al. 1968). Plain landscape and leached morainic podsols soils prevail. Annual mean temperature ranges from +6.3 to $+6.7^{\circ} \mathrm{C}$ and temperatures of the warmest and coldest months (July and January) are from +16.5 to +17.5 and from -5.0 to $-4.7^{\circ} \mathrm{C}$, respectively. The annual mean precipitation is 650 to $750 \mathrm{~mm}$. Period with snow continues from 75 to 90 days (Bukantis 1994). Dominant tree species are Picea abies, Pinus sylvestris, Betula pendula, Betula pubescens, Populus tremula, Fraxinus excelsior, Quercus robur, Tilia cordata. The landscape was extensively fragmented due to forest conversion to agricultural and urban areas in the XIX century.

\section{Vegetation sampling}

Eight study sites were chosen in well developed agricultural grassland and forest edges, which were formed at least 50 years ago (four sites in pine dominated and four sites in spruce dominated semi-natural forests). Sites were chosen to minimise slope, 
canopy heterogeneity, human disturbance and local variation in other factors, which might affect the species composition. Four transects were established in each site. Transects began at the bases of trees that formed the edges and extended perpendicularly in to the forest. The length of transects was $30 \mathrm{~m}$. At the each transect square plots $(1 \times 1 \mathrm{~m})$ were set up at distances of $0 \mathrm{~m}, 5 \mathrm{~m}, 10 \mathrm{~m}, 15 \mathrm{~m}, 20 \mathrm{~m}, 25 \mathrm{~m}$ and 30 $\mathrm{m}$ from the forest edge.

Vegetation sampling was conducted during July and August in 2008. All herbaceous species and mosses were recorded and percentage cover of each species was estimated at each plot. Overall herbs and mosses cover was also estimated. Nomenclature according Jankeviciene (1998) was used.

\section{Data analysis}

The effect of the edge on overall herbaceous species composition (using the percentage cover as abundance parameter) of coniferous forests was evaluated by Canonical Correspondence Analysis (CCA) (Jongman et al. 1995) using the software CANOCO for Windows (ter Braak and Šmilauer 2002). Transect identifiers were used as covariables to analyse the response to the distance to the forest edge. Significance of CCA was tested using the distribution-free Monte Carlo test (999 permutations).

In order to estimate the reaction of each species to the edge effect, the indicator values of each species were calculated specified distances to the forest edge. Indicator values of species were determinated using Dufrene and Legendre method (1997). This method combines information on the concentration of species abundance and faithfulness of the species occurrence at a particular distance from the edge. These were tested for statistical significance using a Monte Carlo technique. Indicator value ranged from zero (no indication) to 100 (perfect indication).

In order to estimate the effect of climatic and edaphic variables on the species composition in relation to forest edge, species indicator values of Ellenberg (Ellenberg et al. 1992) were used for the light $(\mathrm{L})$, soil moisture $(\mathrm{F})$, reaction $(\mathrm{R})$ and nitrogen $(\mathrm{N})$ factors. Indifferent species were excluded from analyses. Indicator values of all species present at the site were averaged in proportion to species percentage cover.

Correlation analysis was applied to assess the relation between species number, cover of herb and moss layers and Ellenberg indicator values to the distance to forest edge. The linear models were fitted to data. The differences at specified distances were assessed by ANOVA. CANOCO software was used for the CCA analyses, PC-ORD software - for the indicator species values calculation and STATISTICA software - for other analyses.

\section{Results}

The species richness of herbs and mosses in coniferous forest was highest in the forest edge and declined towards the interior (Fig. 1a). The highest decrease in the number of species was observed within 0 to $5 \mathrm{~m}$ to the edge. The number of species stabilised in the distance of $20 \mathrm{~m}$ to the edge. The highest
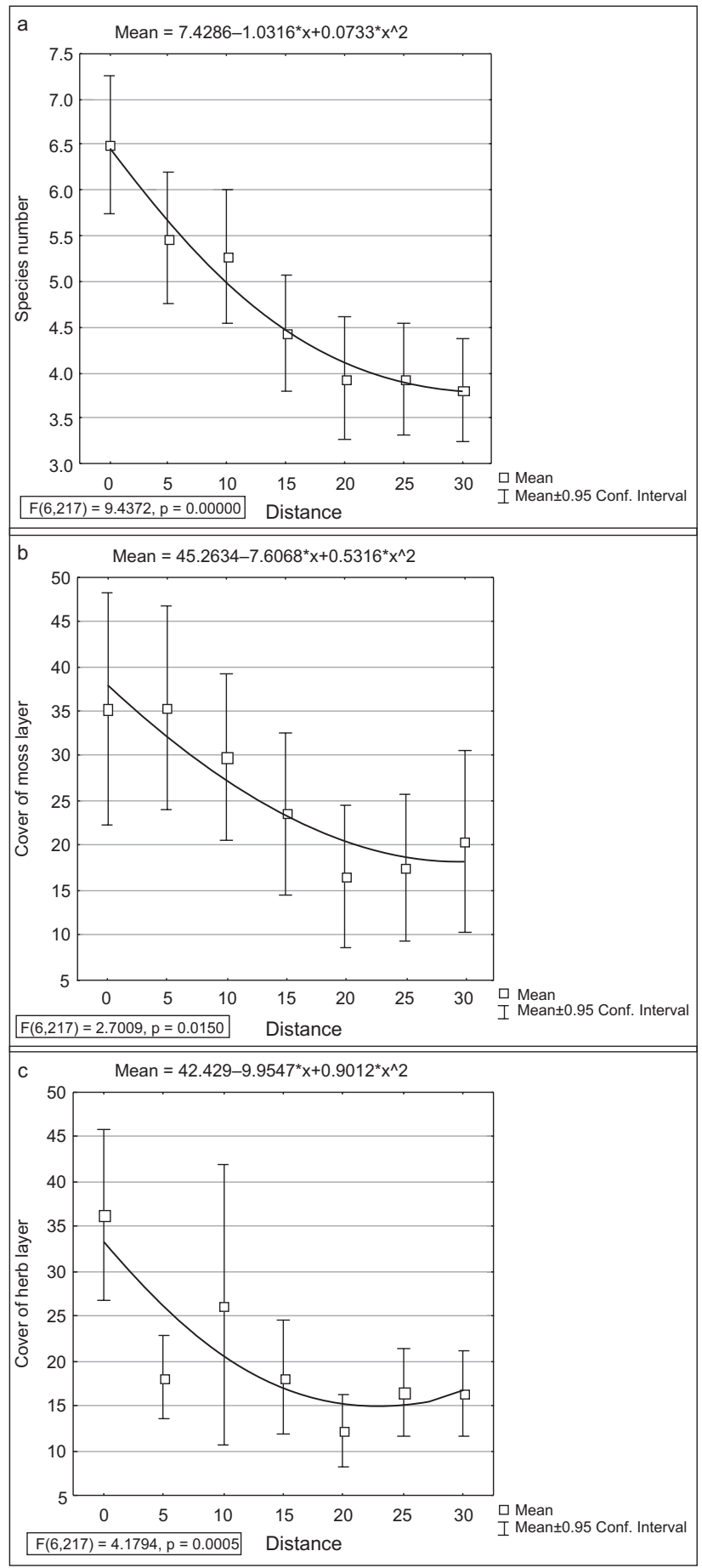

Fig. 1. Change of number of species (a), cover of moss layer (b) and cover of herb layer (c) along the edge-to-interior gradient in coniferous forests ( $\mathrm{F}$ - Fisher test; $\mathrm{p}$ - significance, distance - distance from the forest edge) 


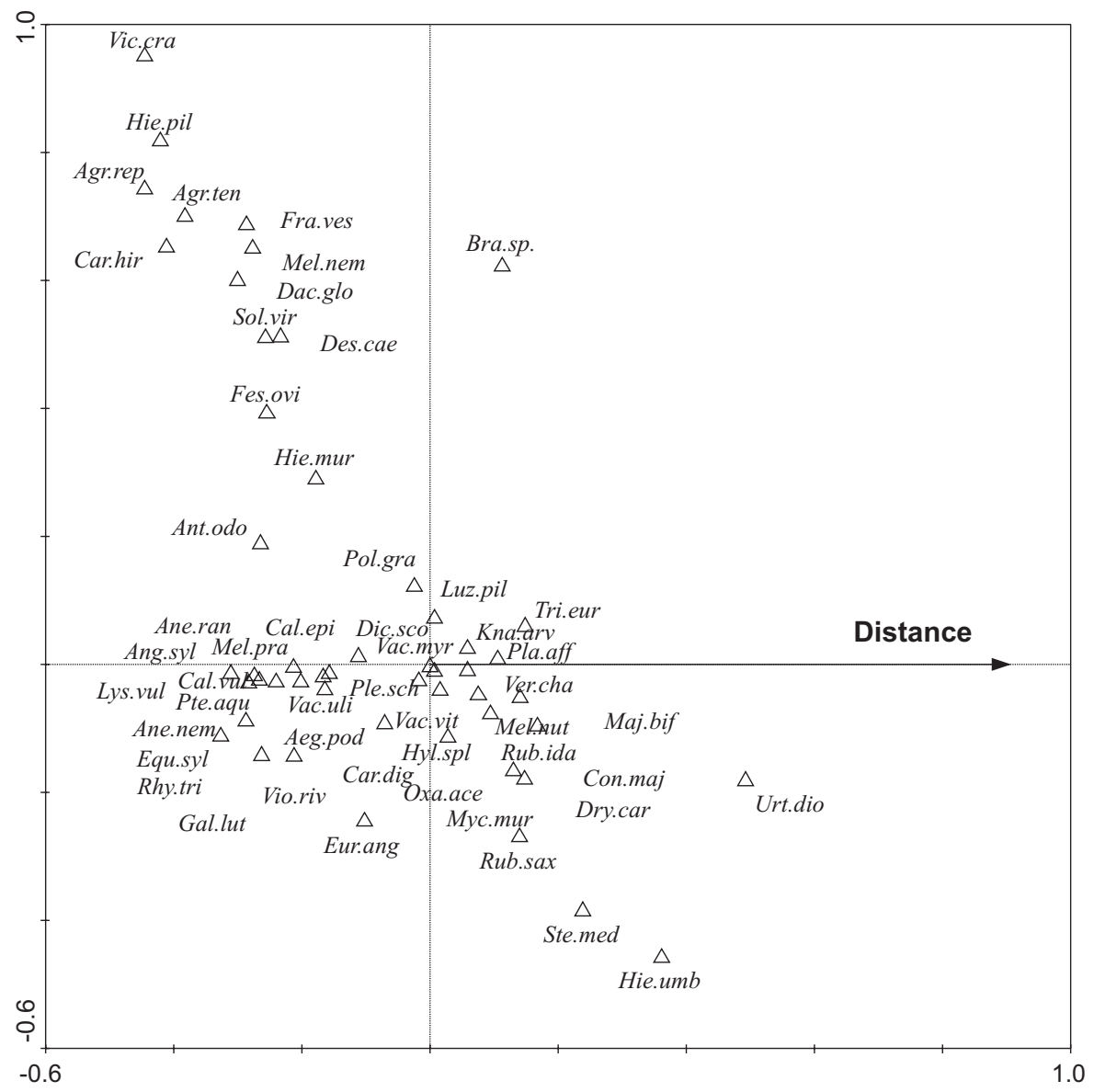

Fig. 2. Canonical correspondence analysis of ground vegetation in coniferous forests (Distance - distance from the forest edge)

Aeg.pod - Aegopodium podagraria, Agr.rep - Agropyron repens, Agr.ten - Agrostis tenuis, Ane.nem - Anemone nemorosa, Ane.ran - Anemone ranunculoides, Ang.syl - Angelica sylvestris, Ant.odo - Anthoxanthum odoratum, Bra.sp. - Brachythecium sp., Cal. epi - Calamagrostis epigejos, Cal.vul - Calluna vulgaris, Car.dig - Carex digitata, Car.hir - Carex hirta, Con.maj - Convallaria majalis, Dac.glo - Dactylis glomerata, - Des.ces - Deschampsia cespitosa, Dic.sco - Dicranus scoparium, Dry.car - Dryopteris carthusiana, Dry.dil - Dryopteris dilatata, Equ.pra - Equisetum pratense, Equ.syl - Equisetum sylvaticum, Eur.ang - Eurhynchium angustirete, Fes.ovi - Festuca ovina, Fra.ves - Fragaria vesca, Gal.lut - Galium luteum, Hie.mur - Hieracium murorum, Hyl. spl - Hylocomium splendens, Lys.vul - Lysimachia vulgaris, Luz.pil - Luzula pilosa, Kna.arv - Knautia arvensis, Mai.bif - Maianthemum bifolium, Mel.nem - Melampyrum nemorosum, Mel.pra - Melampyrum pratense, Mel.nut - Melica nutants, Myc.mur - Mycelis muralis, Oxa.ace - Oxalis acetosella, Pil.off. - Pilosella officinarum, Pla.aff - Plagiomnium affine,Pte.aqu - Pteridium aquilinum, Ple.sch - Pleurozium schreberi, Pol.gra - Polytrichum gracile, Rhy.tri - Rhytidialphus triquetrus, Rub.ida - Rubus idaeus, Rub.sax - Rubus saxatilis, Sol.vir - Solidago virgaurea, Ste.med - Stellaria media, Tri.eur - Trientalis europaea, Urt. dio - Urtica dioica, Vac.myr - Vaccinium myrtillus, Vac.vit - Vaccinium vitis-idaea, Vac.uli - Vaccinium uliginosum, Ver.cha Veronica chamaedrys, Vic.cra - Vicia cracca, Vio.riv - Viola riviniana.

cover of herbs and mosses was in the forest edge and decreased towards the interior (Fig. 1b, c). The difference in cover from the forest edge to forest interior reached up to two times. At the edge, the cover of herbs and mosses was almost two-fold higher.

CCA biplot shows the relationship between overall species composition and the distance to the forest edge (Fig. 2). Correlation of overall species composition and the distance was 0.593; Monte Carlo test: $F-6.179 ; p=0.0010$. That means that distance to the forest edge explains the substantial part of the species composition variation in the habitat.

Species found only at the forest edge were (Table 1): Agrostis tenuis, Angelica sylvestris, Calluna vulgaris,
Carex hirta, Equisetum sylvaticum, Hieracium pilosella, Pteridium aquilinum, Vaccinium uliginosum. The following species were more prevalent at the edge, but were still present up to $10 \mathrm{~m}$ into the interior: Anemone nemorosa, Anemone ranunculoides, Anthoxantum odoratum, Calamagrostis epigejos, Dactylis glomerata, Festuca ovina, Fragaria vesca, Lysimachia vulgaris, Melampyrum nemorosum, Dicranum scoparium, Rhytidialphus triquetrus. Species found in the forest interior included: Convallaria majalis, Mycelis muralis, Urtica dioica (Table 1).

Distribution of species along the edge-to-interior gradient depended on the species response to the various ecological factors. Ellenberg indicator values of light and nitrogen significantly correlated with the 
Effect of the coniferous forest - grassland edge on ground vegetation...

Table 1. Changes of indicator value of species along the edge-to-interior gradient in coniferous forests

\begin{tabular}{|c|c|c|c|c|c|c|c|c|}
\hline \multirow{2}{*}{ Name of species } & \multicolumn{7}{|c|}{ Distance from the forest edge, $m$} & \multirow[b]{2}{*}{$\mathrm{p}^{*}$} \\
\hline & 0 & 5 & 10 & 15 & 20 & 25 & 30 & \\
\hline Aegopodium podagraria & 0 & 5 & 1 & 0 & 0 & 0 & 0 & 0.2671 \\
\hline Agropyron repens & 6 & 0 & 0 & 0 & 0 & 0 & 0 & 0.1306 \\
\hline Agrostis tenuis & 10 & 0 & 0 & 0 & 0 & 0 & 0 & 0.0108 \\
\hline Anemone nemorosa & 6 & 5 & 1 & 0 & 0 & 0 & 0 & 0.0480 \\
\hline Anemone ranunculoides & 7 & 3 & 0 & 0 & 0 & 0 & 0 & 0.0412 \\
\hline Angelica sylvestris & 9 & 0 & 0 & 0 & 0 & 0 & 0 & 0.0176 \\
\hline Anthoxanthum odoratum & 13 & 4 & 3 & 0 & 0 & 0 & 0 & 0.0032 \\
\hline Calamagrostis epigeios & 13 & 1 & 1 & 0 & 0 & 0 & 0 & 0.0026 \\
\hline Calluna vulgaris & 22 & 0 & 0 & 0 & 0 & 0 & 0 & 0.0002 \\
\hline Carex digitata & 0 & 1 & 3 & 1 & 0 & 0 & 1 & 0.5563 \\
\hline Carex hirta & 13 & 0 & 0 & 0 & 0 & 0 & 0 & 0.0032 \\
\hline Convallaria majalis & 0 & 0 & 0 & 0 & 0 & 9 & 2 & 0.0192 \\
\hline Dactylis glomerata & 10 & 5 & 2 & 0 & 0 & 0 & 0 & 0.0238 \\
\hline Deschampsia caespitosa & 0 & 2 & 1 & 0 & 1 & 0 & 0 & 1.0000 \\
\hline Dryopteris carthusiana & 0 & 0 & 0 & 1 & 3 & 2 & 1 & 0.4525 \\
\hline Equisetum sylvaticum & 16 & 0 & 0 & 1 & 0 & 0 & 0 & 0.0004 \\
\hline Festuca ovina & 25 & 3 & 2 & 0 & 0 & 0 & 0 & 0.0002 \\
\hline Fragaria vesca & 12 & 0 & 1 & 0 & 0 & 0 & 0 & 0.0116 \\
\hline Galeobdolon luteum & 0 & 2 & 2 & 0 & 1 & 0 & 0 & 0.6477 \\
\hline Hieracium murorum & 3 & 1 & 5 & 0 & 0 & 0 & 1 & 0.2775 \\
\hline Hieracium pilosella & 10 & 0 & 0 & 0 & 0 & 0 & 0 & 0.0092 \\
\hline Hieracium umbellatum & 0 & 0 & 0 & 0 & 0 & 2 & 2 & 1.0000 \\
\hline Luzula pilosa & 0 & 1 & 3 & 2 & 2 & 1 & 2 & 0.9354 \\
\hline Lysimachia vulgaris & 10 & 2 & 0 & 0 & 0 & 0 & 0 & 0.0172 \\
\hline Knautia arvensis & 1 & 0 & 1 & 8 & 0 & 0 & 0 & 0.0620 \\
\hline Majanthemum bifolium & 0 & 1 & 1 & 6 & 3 & 5 & 4 & 0.6311 \\
\hline Melampyrum nemorosum & 9 & 2 & 0 & 0 & 0 & 0 & 0 & 0.0128 \\
\hline Melica nutans & 0 & 0 & 0 & 4 & 1 & 0 & 0 & 0.3983 \\
\hline Melampyrum pratense & 6 & 4 & 1 & 0 & 0 & 0 & 0 & 0.1860 \\
\hline Mycelis muralis & 0 & 0 & 3 & 5 & 13 & 9 & 6 & 0.0252 \\
\hline Pteridium aquilinum & 9 & 0 & 0 & 0 & 0 & 0 & 0 & 0.0188 \\
\hline Rubus saxatilis & 1 & 0 & 1 & 0 & 0 & 4 & 4 & 0.3459 \\
\hline Solidago virgaurea & 3 & 4 & 0 & 0 & 0 & 0 & 0 & 0.2270 \\
\hline Stellaria media & 0 & 0 & 0 & 1 & 1 & 1 & 1 & 1.0000 \\
\hline Trientalis europaea & 0 & 0 & 2 & 3 & 0 & 2 & 3 & 0.9228 \\
\hline Urtica dioica & 0 & 0 & 0 & 0 & 0 & 2 & 8 & 0.0450 \\
\hline Vaccinium uliginosum & 19 & 0 & 0 & 0 & 0 & 0 & 0 & 0.0002 \\
\hline Veronica chamaedrys & 1 & 0 & 1 & 4 & 0 & 0 & 0 & 0.3775 \\
\hline Vicia cracca & 6 & 0 & 0 & 0 & 0 & 0 & 0 & 0.1422 \\
\hline Viola riviniana & 0 & 6 & 1 & 1 & 0 & 0 & 0 & 0.1168 \\
\hline Dicranum scoparium & 7 & 11 & 1 & 0 & 0 & 0 & 0 & 0.0040 \\
\hline Plagiomnium affine & 0 & 0 & 3 & 2 & 0 & 8 & 2 & 0.1394 \\
\hline Pleurozium schreberi & 0 & 1 & 3 & 0 & 2 & 0 & 0 & 0.7904 \\
\hline Rhytidiadelphus triquetrus & 13 & 1 & 1 & 0 & 0 & 0 & 0 & 0.0010 \\
\hline
\end{tabular}

${ }^{*} \mathrm{p}$ - Monte Carlo test of significance

distance to the forest edge (Table 2). Light value was higher in the edge, explaining forest edge preference by shade intolerant species (Fig. 3a). Ellenberg value of nitrogen was higher in the forest interior (Fig. 3d), while Ellenberg values of moisture and reaction did not differ significantly at the specified distance to the edge (Fig. 3b, c).
Table 2. Correlation coefficients between Ellenberg indicator values and the distance to the forest edge in coniferous forests

\begin{tabular}{lcc}
\hline \multicolumn{1}{c}{ Indicator values } & Correlation coefficient & $\mathrm{p}$ \\
\hline Light $(\mathrm{L})$ & -0.1892 & 0.004 \\
Moisture (F) & 0.1045 & 0.119 \\
Reaction (R) & 0.0438 & 0.515 \\
Nitrogen (N) & 0.2248 & 0.001 \\
\hline
\end{tabular}




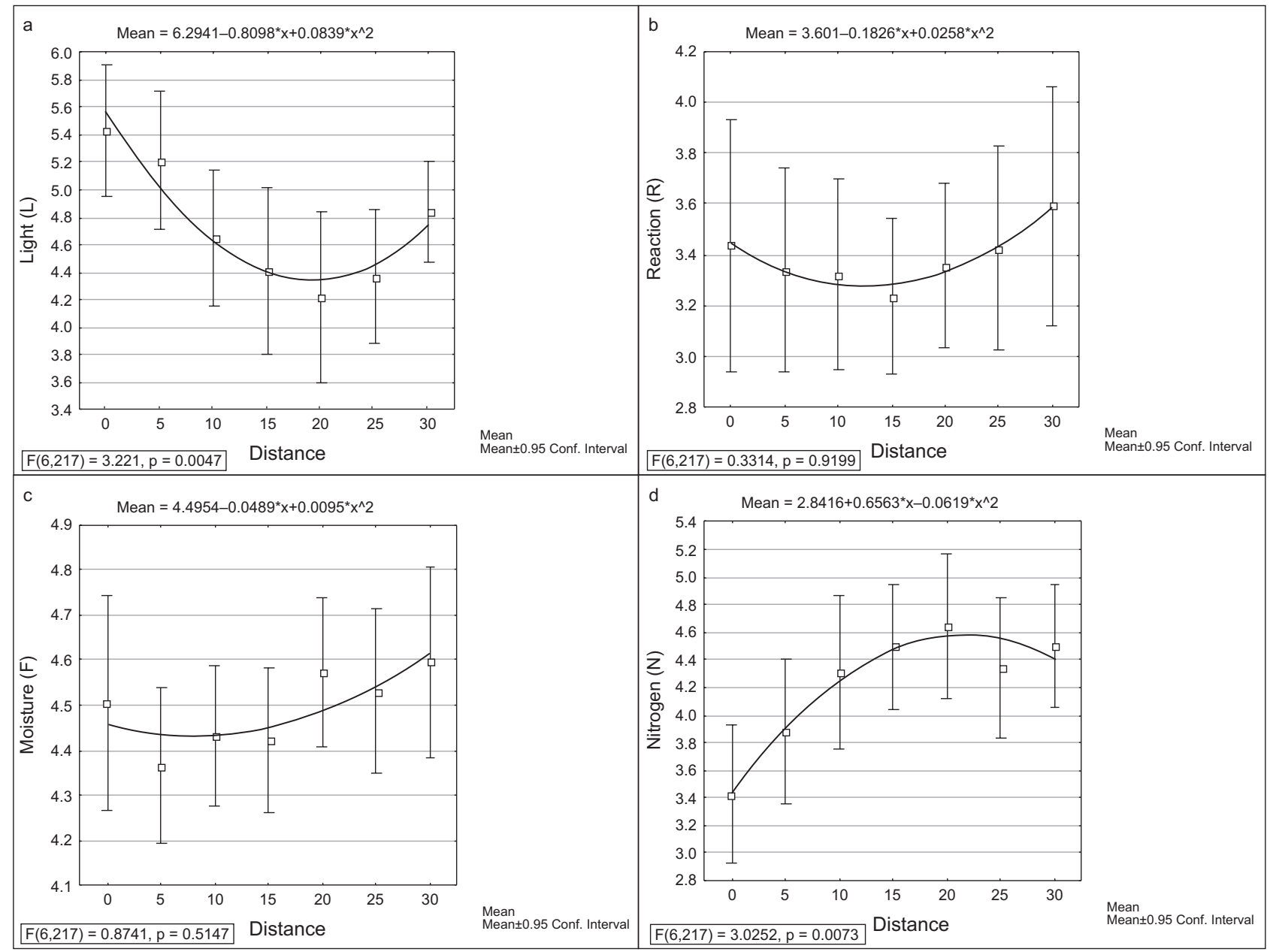

Fig. 3. Changes in mean Ellenberg indicator values along the edge-to-interior gradient in coniferous forests: a) - Light $(\mathrm{L}), \mathrm{b})$ - Moisture (F), c) - Reaction (R), d) - Nitrogen (N). (F - Fisher test; p - significance, distance - distance from the forest edge)

\section{Discussions}

Forest-grassland borders are the common component of human-dominated landscapes. One of the features is the increased species richness at edges (Brothers and Springarn 1992; Matlack 1994; Burke and Nol 1998), although this view has been criticised. The importance of other factors, such as species composition, different abundance of plant species was noticed (Yahner 1988; van der Maarel 1990).

In case of vascular plants and bryophytes, edge effect increases the species richness (Brothers and Springarn 1992; Matlack 1994; Burke and Nol 1998; Orczewska, Glista, 2005). Low densities or complete absence of some forest plant species may occur at the edge, but other species may be more common at or restricted to edge habitats (Chen et al. 1992; Matlack 1994; Fraver 1994; Burke and Nol 1998). In other cases species richness may be lower because of environmental variation (van der Maarel 1990).
In this study the species richness of herbs and mosses was highest at the edge of coniferous forest and declined towards the interior. The main reason of the increased species richness in the edge was the penetration of species from the adjacent grassland. In the forest edge, species with broad ecological diapason, usually intolerant to light shading occurred. In the interior species tolerant to the light shading were frequently found. Investigations in coniferous forest-grassland edges and previous studies have shown that edges are characterised by species that are shade intolerant, have good vegetative reproduction, and are most often associated with early stages of secondary succession (Whitney and Runkle 1981).

Luczaj and Sadowska (1997) found that the forest-grassland border had different characters for various taxonomic groups. The forest-grassland edge is a zone with both maxima and minima of species richness. Burke and Nol found a significant decline in richness and relative cover of the herbaceous layer at $5 \mathrm{~m}$ from the forest edge. 
An increase in the number of invasive species can occur at the edges (Burke and Nol 1998; Honnay et al. 2002; Pauchard and Alaback 2006) as the result of more favourable microclimatic conditions for these species. Species from adjacent agricultural ecosystems can penetrate into a narrow band at the edge of a forest fragment (Murcia 1995) and the presence of these species can result in the modification of the vegetation structure and floristic composition as compared to the interior. Lloyd et al. (2000) concluded that the occurrence of edge species, different species richness in edges and the occurrence of exotic species in edges are all features that depend on the particular ecological conditions, and the ecology of the species present, rather than on intrinsic properties of edges. This study in the coniferous forests-grassland edges showed that grassland species occur only in the narrow band of forest edge.

The extent to which these factors vary with distance from the edge may be influenced by aspect or orientation. Edges facing south and west in the northern hemisphere are typically broader than those facing north and east (Matlack 1993; Fraver 1994; Honnay et al. 2002). Edge effects are reduced by the presence of a protective border. Edge effects can extend from 5 to $200 \mathrm{~m}$, depending on the type of a forest and exposition (Chen et al. 1992; Fraver 1994; Young and Mitchell 1994; Burke and Nol 1998). Honnay et al. (2002) found maximal width of the edge zone more extensive at south facing (ca. 20-23 m) than at north facing (ca. 0-3 m) edges. Gehlhausen (2000) showed that most microclimatic edge effects disappeared within $40-80 \mathrm{~m}$. In temperate zone invasion of disturbance-adapted plants may range from 10 to $30 \mathrm{~m}$ from the edge into the forest interior. Hamberg et al. (2009) concluded that forest edge structure had an effect on understory vegetation and on the spatial extent of the edge effect into the forests. He found that at open edges the edge effect (in terms of the abundances of understory vegetation) penetrated at least up to $30 \mathrm{~m}$ into the forest patches whereas closed edges may prevent these effects.

This study showed that the highest changes in species composition occurred at the distance up to $5 \mathrm{~m}$ to the edge. The edge effect on the species composition was observed up to up to $20 \mathrm{~m}$ into the interior.

\section{References}

Ahti T., Hämet-Ahti L., Jalas J. 1968. Vegetation zones and their sections in northwesten Europe. Annales Botanici Fennici 5: 169-211.

Brothers T.S., Spingarn A. 1992. Forest fragmentation and alien plant invasion of central Indiana oldgrowth forest. Conservation Biology 6: 91-100.

Brothers T.S. 1993. Fragmentation and edge effects in central Indiana old growth forest. Natural Areas Journal 13: 268-275.
Brazaitis G., Roberge J.M., Angelstam P., Marozas V., Petelis K. 2005. Age-related effects of clear-cutold forest edges on bird communities in Lithuania. Scandinavian Journal of Forest Research. 20 (Suppl. 6): 59-68.

Bukantis A. 1994. Lietuvos klimatas. Vilnius, 188 pp. Burke D.M., Nol E. 1998. Edge and fragmented size effects on the vegetation of deciduous forest in Ontario, Canada. Natural Areas Journal 18: 45-53.

Cadenasso M.L., Pickett S.T.A. 2001. Effect of edge structure on the flux of species into forest interiors. Conservation Biology 15: 91-97.

Camargo J.L.C., Kapos V. 1995. Complex edge effects on soil moisture and microclimate in central Amazonian forest. Journal of Tropical Ecology 11: 205-221.

Chen J.Q., Franklin J.E., Lowe J.S. 1996. Comparison of abiotic and structurally defined patch patterns in a hypothetical forest landscape. Conservation Biology 10: 854-862.

Chen J.Q., Franklin J.F., Spies T.A. 1992. Vegetation responses to edge environments in old-growth Douglas-fir forest. Ecological Applications 2: 387-396.

Chen J.Q., Franklin J.F., Spies T.A. 1995. Growing-season microclimatic gradients from clearcut edges into old-growth Douglas-fir forest. Ecological Applications 5: 74-86.

De Casenave J.L., Pelotto J.P., Protomastro J. 1995. Edge-interior differences in vegetation structure and composition in a Chaco semi-arid forest, Argentina - Forest Ecology and Management, 72: 61-69.

Didham R.K., Lawton J.H. 1999. Edge structure determines the magnitude of changes in microclimate and vegetation structure in tropical forest fragments. Biotropica 31: 17-30.

Donovan T.M., Jones P.W., Annand E.M., Thompson III F.R. 1997. Variation in local-scale edge effects: mechanisms and landscape context. Ecology 78: 2064-2075.

Dufrene M., Legendre P. 1997. Species assemblages and indicator species: the need for a flexible asymmetrical approach. Ecological Monographs 67: 345-366.

Ellenberg H., Weber H.E., Wirth V., Werner W., Paulien D. 1992. Zeigerwerte von Pflanzen in Mitteleuropa. Scripta Geobotanica 18: 1-258.

Fletcher R.J. 2005. Multiple edge effects and their implications in fragmented landscapes. Journal of Animal Ecology 74: 342-352.

Fraver S. 1994. Vegetation responses along edge-to-interior gradients in the mixed hardwood forest of the Roanoke river basin, North Carolina. Conservation Biology 8: 822-832.

Gehlhausen S.M., Schwartz M.W., Augspurger C.K. 2000. Vegetation and microclimatic edge effects 
in two mixed-mesophytic forest fragments. Plant Ecology 147: 21-35.

Haila Y. 1999. Islands and fragments. In: Maintaining biodiversity in forest ecosystems, M.L. Hunter (Eds.). Cambridge University Press, Cambridge, U.K. pp. 234-264.

Hamberg L., Lehvävirta S., Kotze D.J. 2009. Forest edge structure as a shaping factor of understorey vegetation in urban forests in Finland. Forest Ecology and Management 257: 712-722.

Hamberg L., Lehvävirta S., Malmivaara-Lämsä M., Rita H., Kotze D.J. 2008. The effects of habitat edges and trampling on understorey vegetation in urban forests in Helsinki, Finland. Applied Vegetation Science 11: 81-96.

Harper K.A., Macdonald S.E., Burton P.J., Chen J., Brosofske K.D., Saunders S.C., Euskirchen E.S., Roberts D., Jaiteh M.S., Esseen P.A. 2005. Edge influence on forest structure and composition in fragmented landscapes. Conservation Biology 19: $768-782$.

Honnay O., Verheyen K., Hermy M. 2002. Permeability of ancient forest edges for weedy plant species invasion. Forest Ecology and Management 161: 109-122.

Jankeviciene R. (eds.) 1998. Dictionary of Plant Names. Institute of Botany Publishers, Vilnius, pp. 523.

Jongman R. H., Braak C. J. F. ter, Tongeren O. F. R. van. 1995. Data Analysis in Community and Landscape Ecology. Pudoc, Wageningen, pp. 299.

Jönsson M.T., Fraver S., Jonsson B.G., Dynesius M., Rydgård M., Esseen P.A. 2007. Eighteen years of tree mortality and structural change in an experimentally fragmented Norway spruce forest. Forest Ecology and Management 242: 306-313.

Jose S., Gillespie A.R., George S.J., Kumar B.M. 1996. Vegetation responses along edge-to-interior gradients in a high altitude tropical forest in peninsular India. Forest Ecology and Management 87: 51-62.

Lin L., Cao M. 2009. Edge effects on soil seed banks and understory vegetation in subtropical and tropical forests in Yunnan, SW China. Forest Ecology and Management 257: 1344-1352. http://dx.doi. org/10.1016/j.foreco.2008.12.004

Lloyd K.M., McQueen A.A.M., Lee B.J., Wilson R.C.B., Walker S., Wilson. J.B. 2000. Evidence on ecotone concepts from switch, environmental and anthropogenic ecotones. Journal of Vegetation Science 11: 903-910.

Luczaj L.,, Sadowska B. 1997. Edge effect in different groups of organisms: vascular plant, bryophyte and fungi species richness across a forest-grassland border. Folia Geobotanica Phytotaxonomica 32: 343-353.

Marozas V., Grigaitis V., Brazaitis G. 2005. Edge effect on ground vegetation in clear-cut edges of pine-dominated forests. Scandinavian Journal of Forest Research 20: 43-49.

Marozas V., Pėtelis K., Brazaitis G., Baranauskaitė J. 2009. Early changes of ground vegetation in fallow deer enclosure. Baltic Forestry. 15: 268-272.

Matlack G.R., Litvaitis J.A. 1999. Forest edges In: Maintaining biodiversity in forest ecosystems, Hunter M.L. (eds.). Cambridge University Press, Cambridge, United Kingdom, pp. 210-233.

Matlack G.R. 1993. Microenvironment variation within and among forest edge sites in the eastern United States. Biological Conservation 66: 185-194.

Matlack G.R. 1994. Vegetation dynamics of the forest edge - trends in space and successional time. Journal of Ecology 82: 113-123.

Murcia C. 1995. Edge effects in fragmented forest: implications for conservation. Trends in Ecology and Evolution 10: 58-62.

Orczewska A., Glista A. 2005. Floristic analysis of the two woodland-meadow ecotones differing in orientation of forest edge. Polish Journal of Ecology 53: 365-382.

Pauchard A., Alaback P.B. 2006. Edge type defines alien plant species along Pinus contorta burned, highway and clearcut forest edges. Forest Ecology and Management 223: 327-335.

Perry D.A. 1994. Forest Ecosystems. Johns Hopkins University Press, Baltimore, pp. 649.

Ries L., Fletcher Jr., R.J., Battin J., Sisk T.D. 2004. Ecological responses to habitat edges: mechanisms, models, and variability explained. Annual Review of Ecology, Evolution and Systematics 35: 491-522.

ter Braak C. J. F. and Šmilauer P. 2002. CANOCO Reference Manual and CanoDraw for Windows User's Guide: Software for Canonical Community Ordination (version 4.5) - Microcomputer Power (Ithaca NY, USA), pp. 500.

Van der Maarel E. 1990. Ecotones and ecoclines are different. Journal of Vegetation Sciences 1: 135138.

Whitney G.G., Runkle J.R. 1981. Edge versus age effects in the development of a beech-maple forest. Oikos 37: 377-381.

Wuyts K., De Schrijver A., Staelens J., Gielis L., Vandenbruwane J., Verheyen K. 2008. Comparison of forest edge effects on throughfall deposition in different forest types. Environmental Pollution, 156: 854-861.

Yahner R.H. 1988. Changes in wildlife communities near edges. Conservation Biology 2: 333-339.

Young A., Mitchell N. 1994. Microclimatic and vegetation edge effect in a fragmented podocarp-broadleaf forest in New Zealand. Biological Conservation 67: 63-72. 